\title{
Efecto de un aditivo extraído de la planta Agave americana sobre las propiedades físicas y mecánicas de un yeso
}

\section{Effect of an admixture from Agave americana on the physical and mechanical properties of plaster}

\author{
J. C. Ochoa $(*)$, M. Bonilla(**), M. V. Borrachero(**), J. Payá(**)
}

Recepción/Received: 3-IX-11

Aceptación/Accepted: $15-\mathrm{VI}-12$

\section{RESUMEN}

Se estudiaron algunas propiedades físicas y mecánicas de pastas de yeso de construcción adicionadas con un aditivo de origen orgánico, producto de las hojas de la planta Agave americana. Se evaluó el comportamiento plástico de la pasta mediante ensayos de consistencia y se determinó, para cada dosificación, su relación agua/ yeso $(a / y)$. Se evaluó la incidencia del aditivo en los tiempos de fraguado. La transformación química del hemihidrato a yeso dihidrato se estudió mediante una novedosa técnica basada en un analizador de humedad por luz halógena. Se midieron las resistencias mecánicas a flexo-tracción y a compresión. Los resultados del estudio muestran que, para una misma consistencia, se mejoran las resistencias mecánicas. Los tiempos de fraguado de la pasta se aumentaron lo que ayudaría mejorar los tiempos de aplicación del yeso y a disminuir las retracciones plásticas. Las modificaciones de estas propiedades físicas no afectan considerablemente las resistencias mecánicas finales.

Palabras clave: aditivo orgánico; yeso; propiedades físicas; hidratación; analizador de humedad por luz halógena.
SUMMARY

Physical and mechanical properties of a plaster paste added with an organic admixture, of the leaves of Agave americana, were studied. Plastic consistency behavior was evaluated and the water/gypsum $(w / g)$ ratio was determined for each dosage of the admixture. Admixtur eeffect on setting was evaluated too. The chemical transformation of the hemihydrated form to gypsum (dihydrated form) was studied using a novel technique based on a moisture analyzer by halogen light. Flexural and compressive strengths were measured. The results show that ,for the same consistency, accordingly mechanical strengths were improved too. The setting times were increased which would enhance the application time of plaster and would reduce plastic shrinkage, common problems in this type of material. The changes in these physical properties not substantially affect the final mechanical strengths.

Keywords: organic admixture; gypsum; physical properties; hydration; halogen moisture analyzer.
(*) Universidad Nacional de Colombia (Medellín, Colombia).

(**) Universitat Politècnica de València (Valencia, España). 


\section{INTRODUCCIÓN}

El yeso es un sulfato de calcio hidratado de origen natural $\left(\mathrm{CaSO}_{4} \cdot 2 \mathrm{H}_{2} \mathrm{O}\right)(1)$. Es un mineral que se presenta combinado con óxidos de hierro y aluminio, con carbonatos de calcio y magnesio, entre otros. El yeso tiene una propiedad única que lo hace valioso para la construcción: cuando se calienta (o calcina) de 100 a $150{ }^{\circ} \mathrm{C}$, pierde tres cuartas partes de su agua de combinación, transformándose en hemihidrato [1].

\section{INTRODUCTION}

Gypsum is natural hydrated calcium sulfate (1). This mineral can appear combined with iron oxide, aluminum oxide, calcium carbonate, magnesium carbonate, etc. Gypsum has a unique property that renders it valuable as a building material: when heated (or calcined) at 100 to $150^{\circ} \mathrm{C}$, it loses three-quarters of its combination water and becomes hemihydrates [1].

$$
\mathrm{CaSO}_{4} \cdot 2 \mathrm{H}_{2} \mathrm{O} \rightarrow \mathrm{Ca} \mathrm{SO} \cdot \frac{1}{2} \mathrm{H}_{2} \mathrm{O}+\frac{3}{2} \mathrm{H}_{2} \mathrm{O} \uparrow
$$

A temperaturas superiores a $150{ }^{\circ} \mathrm{C}$ y $180{ }^{\circ} \mathrm{C}$ pierde el resto de agua de hidratación restante resultando un sulfato de calcio anhidro [2]:
At temperatures beyond $150^{\circ} \mathrm{C}$ and $180^{\circ} \mathrm{C}$, it loses the remaining hydration water, thus becoming anhydrous calcium sulfate [2]:

$$
\mathrm{CaSO}_{4} \cdot \frac{1}{2} \mathrm{H}_{2} \mathrm{O} \rightarrow \mathrm{CaSO}_{4}+\frac{1}{2} \mathrm{H}_{2} \mathrm{O} \uparrow
$$

El yeso utilizado en las edificaciones es producto de la deshidratación del yeso dihidrato $\left(\mathrm{CaSO}_{4} \cdot 2 \mathrm{H}_{2} \mathrm{O}\right)$. Dependiendo de la temperatura de deshidratación, la presión de vapor dentro del horno, el control de calentamiento, la finura y densidad del yeso de origen, se obtienen diferentes productos (2).

Los usos más frecuentes del yeso en la construcción son como recubrimiento, enlucido y material para la fabricación de paneles. En cualquiera de sus usos presenta dos problemas fundamentales: su baja resistencia a agentes exteriores y su corto tiempo de fraguado. Para mejorar su resistencia a agentes exteriores, se usan aditivos como resinas epoxídicas, polímeros, cementos, escorias y otros productos resistentes al agua. La resistencia mecánica de un yeso hemihidrato adicionado con cemento Pórtland y escorias de alto horno, en un ambiente externo a tres años de exposición, es similar a la de un yeso hemihidrato en un ambiente interior ya que se mejora la compacidad de la pasta e incrementa la resistencia al ataque por agua (2). La mezcla de polímeros solubles en agua, generalmente un éter de celulosa, por ejemplo metil celulosa (MC) o metil celulosa modificada (MMC), mejora la resistencia a compresión del yeso $(>5 \mathrm{MPa})$ (3). Sin embargo, el yeso de recubrimiento modificado con látex presenta menores resistencias mecánicas (4). La inclusión de un látex flexible, SBR, en la matriz de yeso, mostró el desarrollo de una red polimérica (PN) que se entreteje con la matriz cerámica y logra incrementar la elasticidad o el comportamiento a la flexión del material al mismo tiempo que se obtiene una baja densidad (5).

Otra alternativa para mejorar la durabilidad del yeso es la impregnación con resinas epoxídicas. Se ha demostrado
The gypsum used in buildings is the product of dehydrating gypsum dihydrate $\left(\mathrm{CaSO}_{4} \cdot 2 \mathrm{H}_{2} \mathrm{O}\right)$. Depending on factors such as dehydration temperature, vapor pressure inside the oven, heating control, fineness, and density of the original gypsum, various products can be obtained (2).

The most frequent uses for gypsum in construction are as stucco, plaster, or as a material for manufacturing panels. Regardless of the way in which it is used, two main problems always arise: its low resistance to external agents and its short setting time. To improve its resistance to external agents, admixtures such as epoxy resins, polymers, cements, slags, and other waterproof products are used. The mechanical strength of hemihydrate gypsum added with Portland cement and slags from a blast furnace in an external environment and after three years of exposition is similar to that of hemihydrate gypsum in an interior environment, since plaster compactness is improved and water resistance increased (2). A mix of water-soluble polymers, usually a type of cellulose ether such as methyl cellulose (MC) or modified methyl cellulose (MMC), improves the compressive strength of gypsum (>5 MPa) (3). Nevertheless, latexmodified plaster has lower mechanical strengths (4). The inclusion of SBR, a flexible type of latex, in the gypsum matrix showed the development of a polymer network (PN) that overlaps the ceramic matrix and manages to increase the material's elasticity or flexural behavior whilst achieving low density (5).

Another alternative for improving gypsum durability is impregnating it with epoxy resins. It has been 
que un yeso impregnado tiene valores de absorción cercanos a cero al final de 7 días de inmersión en agua y conserva su resistencia a compresión (6).

Los yesos utilizados como recubrimiento o enlucido requieren de un buen control del tiempo de fraguado y de una buena consistencia, para facilitar su aplicación y disminuir su retracción. El uso de retardantes, polímeros solubles en agua, agentes aireantes y superplastificantes mejoran la consistencia de la pasta (>150 mm) y el tiempo de fraguado $(>1,5 \mathrm{~h})$. Estos aditivos proporcionan una alta retención de agua y aumentan la consistencia, también la adhesión y la plasticidad del sistema. La aplicación de aditivos aireantes también es importante para la estabilización de los poros generados en el amasado y proveen trabajabilidad y una superficie suave y lustrosa. Estos aditivos también incrementan el volumen de la pasta y el aislamiento térmico y acústico (3). El látex acrílico a base de agua, en grandes dosificaciones, tiende a retardar el proceso de hidratación y reducir la relación agua/yeso (6). La incorporación de látex como el acetato de polivinilo (PVA), el caucho estireno-butadieno (SBR) y el polimetilmetacrilato (PMMA) incrementan el tiempo de fraguado (4). El ácido cítrico actúa con mayor efectividad retardante. La fibra de tabaco también puede ser tan buen retardante como el ácido cítrico (7).

El "yeso aligerado" es frecuentemente utilizado en la fabricación de paneles. Los yesos aligerados se logran por la incorporación de aditivos y agregados ligeros, orgánicos e inorgánicos, tales como perlita expandida o vermiculita. Las burbujas de aire en el yeso de construcción buscan mejorar las prestaciones como aislamiento térmico aunque se disminuyen las resistencias mecánicas (8). El método de la espuma a base de gas utiliza sulfato de aluminio, alumbre de potasio o bicarbonato de amonio para la producción química de burbujas de aire en la pasta de cemento. El sulfato de aluminio es el que mayor cantidad de espuma genera. El alumbre de potasio, lauril sulfato de sodio y el bicarbonato de amonio reducen la densidad del yeso entre el $30 \%$ y el $35 \%$. El bicarbonato de sodio es utilizado como generador de gas, $\mathrm{CO}_{2}$, para la producción de espuma inorgánica a base de yeso y la subsecuente modificación de algunas de sus propiedades. La adición de $1 \%$ por peso de bicarbonato de sodio, a la pasta de yeso, disminuye la conductividad térmica $(K)$, la densidad y las resistencias mecánicas a flexión y compresión (9).La adición de ácido cítrico y carboximetil celulosa, a estas sustancias, ayuda a disminuir la densidad. El esfuerzo a compresión en los yesos de baja densidad cae por debajo de $10 \mathrm{~N} / \mathrm{mm}^{2}$ (10). Algunas investigaciones buscan mejorar tanto las propiedades mecánicas como las aislantes. Una de las estrategias para lograrlo es fabricar una matriz de yeso de alta densidad y agregados de baja densidad. El material demonstrated that the absorption values of impregnated gypsum are close to 0 at the end of a 7-day period of immersion in water. Additionally, it preserves its compressive strength (6).

The types of gypsum used as plaster require a good control of the setting time as well as a good consistency in order to facilitate their application and reduce their shrinkage. The use of retardant agents, water-soluble polymers, air-entraining agents, and superplasticizers improves the plaster's consistency (>150 mm) and setting time $(>1.5 \mathrm{~h})$. These admixtures provide high water retention and increase consistency as well as the adhesion and plasticity of the system. The application of air-entraining admixtures is also important for the stabilization of the pores created during the mixing phase. They also provide workability and produce a smooth and glossy surface. These admixtures also increase plaster volume and the material's thermal and acoustic insulation (3). Large doses of water-based acrylic latex tend to slow down the hydration process and reduce the water/ gypsum ratio (6). The incorporation of latex admixtures such as polyvinyl acetate (PVA), styrene-butadiene rubber (SBR), and polymethylmethacrylate (PMMA) increase setting time (4). Citric acid is a more effective retardant agent. Tobacco fiber can also be as good a retardant as citric acid (7).

The so-called "lightweight gypsum" is frequently used for manufacturing panels. Lightweight gypsum is obtained through the incorporation of admixtures and lightweight, organic, and inorganic aggregates such as expanded perlite or vermiculite. Air bubbles in gypsum plaster are intended to improve advantages such as thermal insulation; however, they reduce mechanical strength (8). The gas-based foam method uses aluminum sulfate, potassium alum, or ammonium bicarbonate to chemically produce air bubbles in the cement paste. Aluminum sulfate is the compound that generates the largest amount of foam. Potassium alum, sodium lauryl sulfate, and ammonium bicarbonate reduce gypsum density between 30 and $35 \%$. Sodium bicarbonate is used to generate gas $\left(\mathrm{CO}_{2}\right)$ for producing gypsum-based inorganic foam and for the subsequent modification of some of its properties. Adding 1\% per weight of sodium bicarbonate to the gypsum plaster decreases thermal conductivity $(K)$, density, and flexural and compressive strengths (9). Adding citric acid and carboxymethyl cellulose to these substances helps reduce density. Compressive stress for the low density types of gypsum drops below $10 \mathrm{~N} / \mathrm{mm}^{2}(10)$. Some research aims at enhancing both the mechanical and insulating properties. One of the strategies for achieving this is to manufacture a high density gypsum matrix and low density aggregates. The most appropriate material found for this purpose contains $5 \%$ of expanded perlite in the gypsum plaster. This mixture 
más favorable encontrado en este propósito contiene $5 \%$, sobre la masa de yeso, de perlita expandida. Se logra con esta mezcla un conductividad térmica de $0.12 \mathrm{~W} \mathrm{~m}^{-1} \mathrm{~K}^{-1}$ y un esfuerzo a la compresión de $2.0 \mathrm{MPa}$ con una densidad aparente igual a $547 \mathrm{~kg} \mathrm{~m}^{-3}$ (11). La incorporación de cenizas volantes, finas y gruesas, las cenizas de fondo y las tierras diatomeas reducen la conductividad térmica e incrementa la protección al fuego (7). La escayola reforzada con fibras de polipropileno y aligerada con perlas de poliestireno expandido permite reducir la densidad y mejorar la resistencia a flexión sobre la escayola sin ningún tipo de adición (8). En morteros de cemento Pórtland y de cal también se han utilizado extractos de origen vegetal para modificar sus propiedades (12-13).

Las plantas de la familia Agavaceae son plantas suculentas de origen americano. En muchos países de Centro y Suramérica su fibra se utiliza para la elaboración de empaques, vestidos, calzados y artesanías, y su licor (extracto líquido) es depositado en cuencas hídricas con un alto impacto contaminante. En el proceso de extracción de la fibra se desecha una gran cantidad de su jugo que, en algunos casos, representa el $70 \%$ del peso de su hoja. En la mayor parte las ocasiones, este residuo es vertido directamente a suelos o ríos, produciendo una contaminación importante. Este residuo se asimila a otros compuestos orgánicos de plantas como los cactus (13), o de vegetales como la remolacha que tienen similares efectos en las propiedades del yeso.

El objetivo de esta investigación fue la reutilización de este residuo vegetal en conglomerantes basados en yeso y la evaluación de su incidencia en algunas propiedades de la pasta de yeso en estado fresco y endurecido. El uso de este residuo como aditivo en materiales conglomerantes ayudaría a mitigar el impacto ambiental que genera y daría valor agregado al cultivo y comercialización de este tipo de plantas suculentas.

\section{MATERIALES Y MÉTODOS}

Para los ensayos correspondientes se utilizó un yeso grueso de construcción, hemihidrato, que se utiliza para pasta de agarre en la ejecución de tabicados, en revestimientos interiores y como conglomerante auxiliar de origen comercial y que se clasifica como tipo B1 (yeso para la construcción) según la norma española (14). Las características físicas de este yeso se muestran en la Tabla 1.

Como aditivo orgánico se utilizó el extracto de la especie Agave americana (pitera) que es la planta suculenta más conocida en España junto con la Opuntia sp. Se trata de una planta que pertenece a la familia Agavaceae. Mide de 2 a $3 \mathrm{~m}$ de ancho, las hojas son gruesas, lanceoladas achieves a thermal conductivity value of $0.12 \mathrm{~W} \mathrm{~m}^{-1}$ $K^{-1}$ and a compressive strength of 2.0 MPa with an apparent density of $547 \mathrm{~kg} \mathrm{~m}^{-3}$ (11). Incorporating fly ash (both fine and coarse), bottom ash, and diatomaceous earth reduces thermal conductivity and increases fire protection (7). Plaster that is reinforced with polypropylene fibers and lightened with expanded polystyrene beads reduces the density and improves the flexural strength of plaster without requiring any addition (8). Plant extracts have also been used in Portland cement and lime mortars to modify their properties (12-13).

Plants from the Agavaceae family are succulent plants that originated in the Americas. In many countries in Central and South America, their fiber is used to make packaging, clothing, footwear, and handicraft. Also, their liquor (liquid extract) is poured in watersheds, a practice with an important polluting impact. Moreover, a large amount of their juice - which in some cases represents $70 \%$ of the leaves' weight- is discarded during the fiber extraction process. In most cases, this waste material is dumped directly into soil or rivers, causing significant pollution. This waste materialis similar to other organic compounds found in plants such as cacti (13) or beet, which have similar effects on the properties of gypsum.

The objective of this study was to reuse this vegetable waste material in gypsum-based binders and to assess its impact on some of the properties of fresh and hardened gypsum plaster. The use of this waste material as an admixture in binders could help reduce the environmental impact generated by the aforementioned practices and would also give added value to the cultivation and marketing of this type of succulent plants.

\section{MATERIALS AND METHODS}

For the corresponding tests, coarse construction gypsum (hemihydrate) was used. This type of gypsum is used as plaster for walls, stucco, auxiliary binders, and as a commercial type of binding. It is classified as type B1 (construction gypsum) according to the Spanish standard (14). In Table 1 physical properties of plaster are shown.

As organic admixture, we used the extract from the Agave Americana (maguey) plant, which, together with Opuntia $s p$, is the most popular succulent plant known in Spain. This plant belongs to the Agavaceae family, and is 2 to 3 meters wide. Its leaves are thick, bluish, lanceolate, 
Tabla 1 / Table 1

Características físicas del yeso.

Physical properties of plaster.

\begin{tabular}{|c|c|}
\hline \multicolumn{2}{|c|}{ Yeso tipo YG / YG-type gypsum } \\
\hline Índice de pureza / Purity index & $75 \%$ \\
\hline $\mathrm{pH}$ mínimo / Minimum pH & $50 \%$ \\
\hline Finura de molido / Fineness of grind & 8 minutos / minutes \\
\hline Principio de fraguado / Initial setting time & 10 minutos / minutes \\
\hline Final de fraguado / Final setting time & $2.0 \mathrm{MPa}$ \\
\hline
\end{tabular}

de color azulado y se hallan bordeadas de espinas. Pueden llegar a medir más de 1,75 m de largo y 0,30 m de ancho. Los constituyentes se conocen en forma cualitativa son básicamente agua, celulosa, materia orgánica (sacarosa, proteínas, nitrógeno, fósforo, calcio, potasio, saponinas y sapogeninas) y minerales.

Las hojas se recogieron en los términos municipales de Paterna y de Bétera, en la provincia de Valencia (España). Fueron empacadas en bolsas de polietileno y transportadas hasta el laboratorio, donde en el transcurso de las siguientes 24 horas fueron procesadas. El aditivo orgánico tuvo un contenido en agua del $92 \%$. El residuo sólido contenía un $91 \%$ de materia orgánica. La licuadora utilizada permitió separar la fibra más larga y exprimir el licor. El líquido obtenido de cada sección se pesó para conocer el rendimiento relativo al peso de la hoja, se envasó en pequeños botes con $25 \mathrm{~g}$, cada uno, y se congeló inmediatamente. Allí permaneció, a una temperatura promedio de $-14{ }^{\circ} \mathrm{C}$, hasta que fue utilizado. El mayor porcentaje de extracto, respecto al peso total de la hoja, se obtuvo de la base de la hoja (aprox. 70\%), por concentrarse allí el tejido carnoso y el agua. Las secciones media y la punta, aportaron menos cantidad de extracto. Para este estudio se adicionó $1 \%, 3 \%$ y $5 \%$ de aditivo a las pastas de yeso.

La relación agua/yeso $(a / y)$ se determinó mediante el método de ensayo-error, de la norma UNE EN-13279-2 (15), que consiste en rellenar con la pasta un cono truncado, se levanta y golpea en la mesa de sacudidas, hasta que se forme una galleta de un diámetro determinado $(165 \pm 5 \mathrm{~mm})$.

Los tiempos de fraguado, inicial y final, se midieron siguiendo la norma UNE EN-13279-2 (15). Se determinó la profundidad de la penetración de la aguja o del cono de Vicat dentro de una pasta de yeso a medida que progresa el fraguado.

Para medir las resistencias mecánicas se fabricación probetas de $40 \mathrm{~mm}$ x $40 \mathrm{~mm} \times 160 \mathrm{~mm}$. El curado se efectuó durante cinco (5) días en cámara húmeda (humedad relativa $90 \% \pm 5 \%$ ) y dos (2) días en estufa a $40{ }^{\circ} \mathrm{C} \pm 2{ }^{\circ} \mathrm{C}$. and lined with thorns. They can be more than $1.75 \mathrm{~m}$ long and $0.3 \mathrm{~m}$ wide. Constituents were known qualitatively; they are basically water, cellulose, organic matter (saccharose, protein, nitrogen, phosphorus, calcium, potassium, saponins and sapogenins) and minerals.

The leaves were collected in the municipalities of Paterna and Bétera, in the province of Valencia (Spain). They were packed in polyethylene bags and transported to the laboratory, where they were processed within the next 24 hours. The organic admixture had a water content of $92 \%$. The solid residues contained $91 \%$ of organic matter. The blender used made it possible to separate the longer fibers and squeeze the liquor. The liquid obtained from each section was weighed to determine performance relative to the leaf weight. It was the stored in small $25 \mathrm{~g}$ bottles and frozen immediately. It was kept at a temperature of $-14^{\circ} \mathrm{C}$ until it was used. The highest percentage of extract in relation to a leaf's total weight is obtained from the base of the leaf (approximately $70 \%$ ) as it is there where the fleshy tissue and water are concentrate; the middle section and the tip of the leaves provide less extract. In this study, we added 1\%, 3\% and $5 \%$ of admixture to the plaster.

The water/gypsum $(w / g)$ ratio was determined through the trial and error method described in the UNE EN13279-2 standard (15). This method involves filling a truncated cone with the plaster, then rising and striking it at the flow table until it forms a circle of a given diameter $(165 \pm 5 \mathrm{~mm})$.

The initial and final setting times were measured using the UNE EN-13279-2 standard (15). The penetration depth of the Vicat needle in gypsum plaster was determined as the setting process progressed.

To measure mechanical strengths, test samples measuring $40 \mathrm{~mm} \times 40 \mathrm{~mm} \times 160 \mathrm{~mm}$ were prepared. Curing was carried out for five (5) days in a moist chamber (relative humidity $90 \% \pm 5 \%$ ) and two (2) days in an oven at $40^{\circ} \mathrm{C} \pm 2{ }^{\circ} \mathrm{C}$. 
El cálculo de la cantidad de hemihidrato que contiene el yeso en polvo y la cantidad que se transforma en dihidrato se llevó a cabo a partir de los datos obtenidos con el analizador halógeno de humedad Mettler Toledo HR73-P. Este aparato permite calentar una muestra sólida pulverulenta (mediante una fuente de halógenos), a una temperatura determinada, hasta que no se detecta pérdida de peso apreciable (agua en el caso de dihidrato y hemihidrato). Para cada tiempo de reacción, la muestra fraguada se machacó en un mortero con acetona, se filtró y el sólido recogido se secó en estufa a $60^{\circ} \mathrm{C}$ durante 30 minutos. El calentamiento se realizó desde $25^{\circ} \mathrm{C}$ hasta $180^{\circ} \mathrm{C}$. En este estudio se utilizaron muestras en polvo de aproximadamente $5 \mathrm{~g}$ de peso y se midió la pérdida de peso cada 30 segundos hasta que esta fuera inferior al $0,02 \%$ del peso de la muestra. El registro no permite identificar la descomposición intermedia desde dihidrato a hemihidrato: la pérdida de peso se atribuye al agua combinada químicamente en el dihidrato formado y en el hemihidrato sin reaccionar. Este método se ha validado previamente (16) comparando los resultados obtenidos por análisis termogravimétrico.

\section{RESULTADOS Y DISCUSIÓN}

\subsection{Influencia del aditivo en la relación agua/ yeso y en la consistencia de la pasta}

En primer lugar se determinó la influencia en la relación $\mathrm{a} / \mathrm{y}$. Se realizaron varias amasadas de tal manera la incorporación del aditivo permitía que se disminuyera el agua para mantener constante la consistencia, cuantificada como el diámetro de la galleta en la mesa de sacudidas $165 \pm 5 \mathrm{~mm}$.

En la Tabla 2 se observa cómo a medida que se aumenta el porcentaje de aditivo, $1 \%$, $3 \%$ y $5 \%$, se disminuye la cantidad de agua requerida para alcanzar la misma consistencia. Con el $1 \%$ se aprecia una disminución considerable del agua de amasado respecto a la muestra control. A partir de allí las disminuciones son menos importantes cuantitativamente, hasta llegar a diferencias mínimas como en el caso del $3 \%$ y el $5 \%$.

Para determinar el efecto del plastificante en la consistencia se efectuaron amasadas, conservando la misma relación a/y 0,48, y se midió el diámetro de la galleta en la mesa de sacudidas.

En la Tabla 3 se presenta la influencia del aditivo en la consistencia de la pasta. Se observa que, a la misma relación a/y, y con 1\% (muestra 1b) de aditivo, la plasticidad de la pasta se incrementa un $11 \%$ aproximadamente respecto de la muestra control $(165 \mathrm{~mm})$, y al pasar de
The amount of hemihydrate contained in the gypsum powder and the amount that transformed into dihydrate were calculated using the data obtained with a Mettler Toledo HR73-P halogen moisture analyzer. This device makes it possible to heat a powdery solid sample (through a halogen source) at a given temperature until no significant weight loss is detected (water in the case of dihydrate and hemihydrate). For each reaction time, the set sample was crushed in a mortar with acetone. It was then filtered, and the collected solid matter was dried in an oven at $60^{\circ} \mathrm{C}$ for 30 minutes. Matter was heated at $25^{\circ} \mathrm{C}$ to $180{ }^{\circ} \mathrm{C}$. In this study, we used powdered samples weighing approximately $5 \mathrm{~g}$. Weight loss was measured every 30 seconds until it was less than $0.02 \%$ of the sample weight. The record does not allow for the identification of the intermediate decomposition from dihydrate into hemihydrate: the loss of weight is attributed to the chemically combined water in the produced dihydrate and in the un reacted hemihydrate. This study was previously validated (16) by comparing the results obtained from thermogravimetric analysis.

\section{RESULTS AND DISCUSSION}

\subsection{Influence of the admixture on the water/ gypsum ratio and on plaster consistency}

First, the influence on the $\mathrm{w} / \mathrm{g}$ ratio was determined. Several mixes were made so that incorporating admixture allowed us to reduce the amount of water to maintain a constant degree of consistency, which is measured as the diameter of the circle in the flow table $165 \pm 5 \mathrm{~mm}$.

Table 2 shows how increasing the percentage of admixture in $1 \%, 3 \%$ and $5 \%$ reduced the amount of water required to reach maximum consistency. With $1 \%$, a considerable decrease in mixing water was observed compared to the control sample. From that point on, the decreases were less significant in quantitative terms. Upon reaching 3\% and 5\% of admixture, the differences became minimal.

To determine the effect of the plasticizer on the consistency, we made several mixes whilst keeping the same $w / g$ ratio -0.48 - and measuring the diameter of the circle in the flow table.

Table 3 shows the influence of the admixture on the plaster's consistency. We can observe that, with the same $\mathrm{w} / \mathrm{g}$ ratio and $1 \%$ of admixture (sample $1 \mathrm{~b}$ ), plaster plasticity increases approximately in $11 \%$ compared to the control sample $(165 \mathrm{~mm})$. Also, upon increasing 
Tabla 2 / Table 2

Efecto del aditivo en la relación a/y. Consistencia constante $165 \pm 5 \mathrm{~mm}$. Effect of additive in $\mathrm{w} / \mathrm{g}$ ratio. Constant consistency $165 \pm 5 \mathrm{~mm}$.

\begin{tabular}{|c|c|c|c|c|c|c|c|}
\hline \multirow{2}{*}{ Muestra / Sample } & \multirow{2}{*}{$\begin{array}{c}\text { Yeso / } \\
\text { Gypsum (g) }\end{array}$} & \multicolumn{3}{|c|}{ Aditivo / Admixture } & \multirow{2}{*}{$\begin{array}{c}\text { Agua de amasado / } \\
\text { Mixing water (g) }\end{array}$} & \multirow{2}{*}{$\begin{array}{c}\text { Agua total / } \\
\text { Total water (g) }\end{array}$} & a/y / w/g \\
\cline { 3 - 5 } & & $\%$ & $\mathbf{g}^{*}$ & $\mathbf{H}_{\mathbf{2}} \mathbf{O}$ & & 1200.0 & 0.480 \\
\hline 1a & 2500 & 0 & 0 & 0 & 1200.0 & 1065.0 & 0.426 \\
\hline 2a & 2500 & 1 & 25.0 & 24.5 & 1040.0 & 1006.5 & 0.403 \\
\hline 3a & 2500 & 3 & 75.0 & 69.0 & 937.5 & 990.0 & 0.396 \\
\hline 4a & 2500 & 5 & 125.0 & 115.0 & 875.0 & & \\
\hline
\end{tabular}

* El agua del aditivo es el $92 \%$ de la masa total / The amount of water in the admixture is $92 \%$ of the total mass.

1 a $3 \%$ de aditivo, el incremento en la plasticidad es del $19 \%$. Con la adición del $5 \%$ no fue posible determinar la plasticidad porque la fluidez fue tal que desbordó el tablero de la mesa. Esta y la anterior medida nos demuestran que adiciones mayores del $3 \%$ del aditivo en la pasta de yeso no aportan beneficios al material para esa relación a/y $(0,48)$. Este incremento fue superior al encontrado en otros estudios donde se utilizó $0.15 \%$ de superplastificante comercial y una relación a/y $(0,45)$, donde se obtuvieron incrementos en la consistencia del $6 \%$, aproximadamente (3). the amount of admixture to 3\%, plasticity increases in $19 \%$. With $5 \%$ of admixture, we were unable to determine plasticity because fluidity was so high that it overflowed the table's board. This measurement and the previous one demonstrate that additions beyond 3\% of admixture in the gypsum plaster provide no benefits for the material using that $w / g$ ratio $(0.48)$. This increase was higher than the values found in other studies, where $0.15 \%$ of commercial superplasticizer was used at a $\mathrm{w} / \mathrm{g}$ ratio of (0.45). These studies found increases of approximately $6 \%$ in the consistency (3).

Tabla 3 / Table 3

Efecto del aditivo en la consistencia del yeso. Relación a/y constante 0,48. Effect of additive in gypsum consistency. Constant a/y ratio 0.48 .

\begin{tabular}{|c|c|c|c|c|c|c|c|}
\hline \multirow{2}{*}{$\begin{array}{c}\text { Muestra / } \\
\text { Sample }\end{array}$} & \multirow{2}{*}{$\begin{array}{c}\text { Yeso / } \\
\text { Gypsum (g) }\end{array}$} & \multicolumn{3}{|c|}{ Aditivo / Admixture } & \multirow{2}{*}{$\begin{array}{c}\text { Agua de amasado / } \\
\text { Mixing water (g) }\end{array}$} & $\begin{array}{c}\text { Agua total / } \\
\text { Total Water (g) }\end{array}$ & $\begin{array}{c}\text { Consistencia / } \\
\text { Consistency (mm) }\end{array}$ \\
\cline { 3 - 5 } & $\%$ & $\mathrm{~g}$ & $\mathrm{H}_{2} \mathrm{O}$ & & 1200 & 165 \\
\hline 1a & 2500 & 0 & 0 & 0 & 1200 & 1200 & 189 \\
\hline 2b & 2500 & 1 & 25 & 24.5 & 1176 & 1200 & 225 \\
\hline 3b & 2500 & 3 & 75 & 69.0 & 1131 & 1200 & N.D \\
\hline 4b & 2500 & 5 & 125 & 115.0 & 1085 & \\
\hline
\end{tabular}

\subsection{Influencia del aditivo en los tiempos de fraguado del yeso}

Para este ensayo se utilizaron las mismas dosificaciones del ensayo de consistencia que aparecen en las Tablas 2 y 3.

Los resultados obtenidos se observan en la Figura 1. En el gráfico se muestran los tiempos inicial y final de fraguado de las pastas de yeso, 2a, 3a y 4 a de la Tabla 2, que se prepararon con igual consistencia que la de la muestra control (1a) y las muestras $2 b, 3 b$ y $4 b$ de la Tabla 4 que corresponden a las muestras y las pastas con igual relación a/y. Se observa que los tiempos de inicio y final de fraguado, tanto para las pastas de igual consistencia como para las de igual relación $a / y$, aumentan a medida que

\subsection{Influence of the admixture on the gypsum's setting times}

For this test, we used the same dosages described in the consistency test appearing in Tables 2 and 3.

The obtained results can be seen in Figure 1. The graph shows the initial and final setting times for the $2 a, 3 a$, and $4 a$ gypsum plaster samples from Table 2. They were prepared with the same consistency as the control sample (1a). The table also shows samples $2 b, 3 b$, and $4 b$ from Table 4, which correspond to the samples and plaster with the same $w / g$ ratio. We observed that initial and final setting times for both the plaster samples having the same consistency and the ones with the same 
se incrementa el porcentaje de extracto. Los tiempos de fraguado de las pastas con igual relación a/y son mayores que los de las pastas de igual consistencia debido, posiblemente, a la mayor cantidad de agua presente en la muestra. Comparativamente, el uso de ácido cítrico en dosificaciones entre $0,05 \%$ y $0,15 \%$ permite el aumento del tiempo de fraguado de 1 a 7 horas, sin embargo produce una reducción de la trabajabilidad y en la resistencia a compresión entre 11,3 y 8,02 MPa (3). $w / g$ ratio raised as the percentage of extract increased. The setting times of the plaster samples with the same $w / g$ ratio were higher than those of the plaster samples with the same consistency. This could be due to the higher amount of water present in the sample. Comparatively, the use of citric acid in dosages between $0.05 \%$ and $0.15 \%$ made it possible to increase the setting time from 1 to 7 hours. However, this caused a reduction in workability and compressive strength between 11.3 and $8.02 \mathrm{MPa}$ (3).

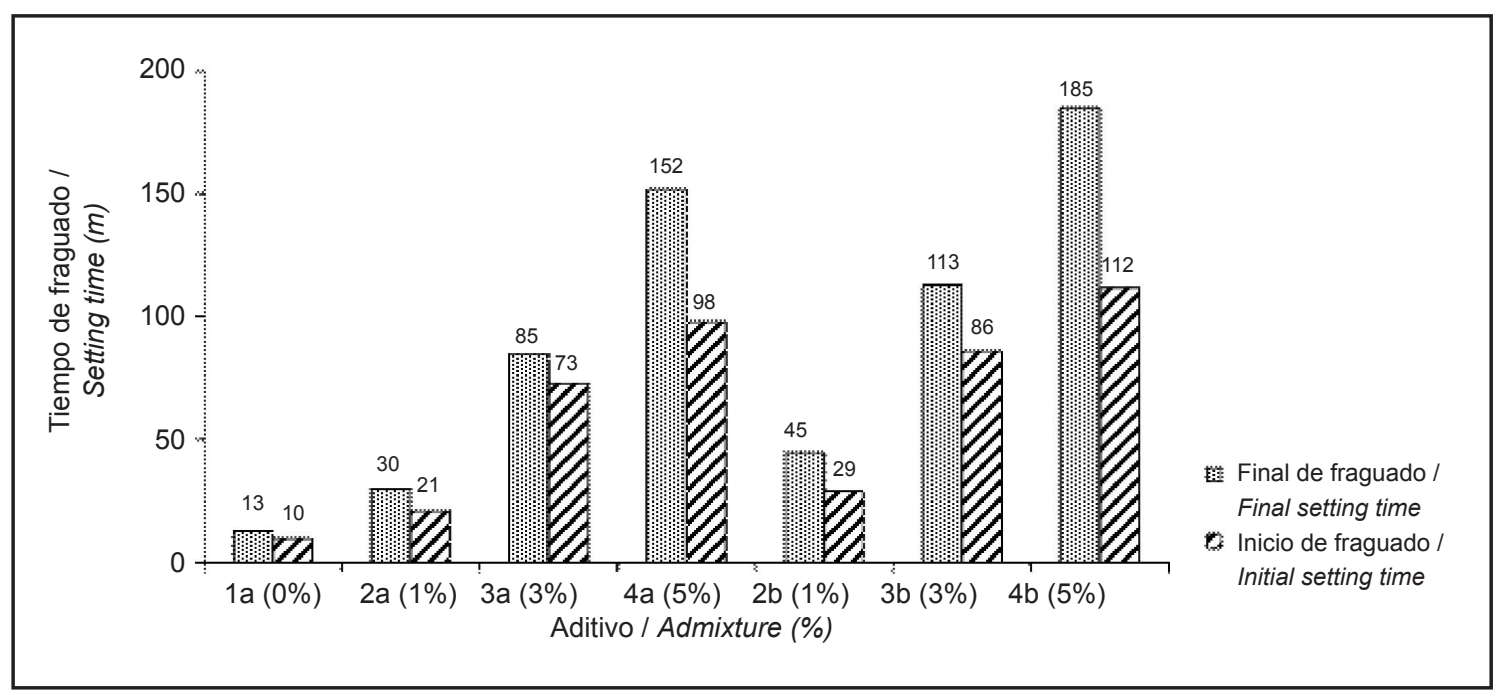

Figura 1. Tiempos de fraguado inicial y final a igual consistencia e igual relación a/y.

Figure 1. Initial and final setting times with the same consistency, and a/y ratio.

Adicionalmente, se llevó a cabo una determinación de la composición del yeso mediante un analizador de humedad que se describió en el capítulo experimental. El método consistió en calentar la muestra muy rápidamente (por lámpara de halógenos), a una temperatura de $180^{\circ} \mathrm{C}$, durante un tiempo suficiente para que la pérdida de masa detectada fuera despreciable.

A partir de los resultados obtenidos se determinó el grado de conversión del yeso hemihidrato a dihidrato. Para ello, previamente, fue secada en la estufa, a $60^{\circ} \mathrm{C}$, una muestra de yeso para eliminar la humedad. A continuación fue sometida al calentamiento en la balanza de halógenos, obteniendo el dato de pérdida total (Pérdida Total para Yeso). En estas condiciones, este dato de pérdida total es debido, únicamente, a la cantidad de agua químicamente combinada en el hemihidrato presente en la muestra de yeso [3]:
Additionally, gypsum composition was determined using the moisture analyzer described in the experimental section of this paper. The method involved heating the sample very quickly (using a halogen lamp) at a temperature of $180^{\circ} \mathrm{C}$ until the detected loss of mass was not significant.

The gypsum's degree of conversion from hemihydrate into dihydrate was determined based on the results obtained. To achieve this, a sample of gypsum was previously dried in an oven at $60^{\circ} \mathrm{C}$ in order to remove moisture. After this, it was heated in the halogen balance, thus obtaining the value for total loss (Total Loss for Gypsum). Under these conditions, this total loss value is due only to the amount of chemically combined water in the hemihydrate inside the gypsum sample [3]:

$$
\mathrm{CaSO}_{4} \cdot \frac{1}{2} \mathrm{H}_{2} \mathrm{O} \rightarrow \mathrm{CaSO}_{4}+\frac{1}{2} \mathrm{H}_{2} \mathrm{O}
$$

Durante la hidratación del yeso se produce la reacción [4]:
There is a reaction during the gypsum hydration process [4]: 


$$
\mathrm{CaSO}_{4} \cdot \frac{1}{2} \mathrm{H}_{2} \mathrm{O}+\frac{3}{2} \mathrm{H}_{2} \mathrm{O} \rightarrow \mathrm{CaSO}_{4} \cdot 2 \mathrm{H}_{2} \mathrm{O}
$$

La reacción no se completa totalmente durante el tiempo de fraguado, sino que solo parte del hemihidrato ha reaccionado con el agua para formar el dihidrato. El resto del hemihidrato sin reaccionar, lo hace más lentamente (después del fraguado), con el exceso de agua que queda en la pasta. Por ello, con el analizador de humedad por halógenos se puede determinar, también, el porcentaje de dihidrato y hemihidrato que contiene una muestra de yeso fraguada, con el tiempo de curado.

Para la aplicación de este método y con el propósito de identificar la acción del aditivo vegetal en el proceso de hidratación de las pastas de yeso, se analizaron mezclas a diferentes tiempos de curado $(0,5,13$ y 24 horas), y se utilizaron la mismas dosificaciones de los estudios de consistencia y tiempos de fraguado, Tablas 2 y 3.

El grado de conversión se evaluó determinando el agua químicamente combinada tanto para la forma hemihidrato como para la forma dihidrato. La primera columna de la Tabla 4 define la muestra de la pasta, la segunda la pérdida de agua combinada en la pasta de yeso, la tercera el porcentaje de dihidrato presente en la pasta hidratada (D), la cuarta el porcentaje de hemihidrato $(H)$ y la quinta el grado de conversión (a).

Se observa que a 0,5 y 1 hora el grado de conversión de las muestras con $3 \%$ y $5 \%$ de aditivo es menor que la de la muestra control. Con 3 y 24 horas el valor es bastante similar. Lo que significa que el poder retardante del aditivo en el yeso se manifiesta considerablemente en las primeras horas de hidratación. También observamos que la formación de dihidrato se sigue incrementando con el tiempo.

En la Tabla 5 se relacionan los datos obtenidos del porcentaje de dihidrato formado a las $0,5,1,3$ y 24 horas de hidratado el yeso, con pastas de igual consistencia que la muestra control y por ende con una variación en la relación $a / y$. El comportamiento del grado de conversión es similar al de las pastas fabricadas con igual relación $a / y$, sin embargo los valores de conversión son menores lo que indica una menor hidratación de la pasta debido, seguramente, a la mayor concentración de las sustancias activas en el extracto de la planta. A pesar de que con igual relación $a / y$, hay un retraso en el fraguado mayor que en las pasta fabricadas a igual consistencia, eso no indica que el porcentaje de conversión final de hemihidrato a dihidrato sea menor. En general podemos decir que el aditivo funciona como un retardante de la formación de los cristales de yeso dihidrato, en la primera hora.
The reaction does not reach completion during the setting time; instead, only a part of the hemihydrate reacts with water to form dihydrate. The rest of the hemihydrate reacts, at a slower rate, with the excess of water remaining in the plaster. This happens after the setting phase. This is why the halogen moisture analyzer also makes it possible to determine the percentage of dihydrate and hemihydrate contained in the set gypsum sample with the curing time.

To apply this method, and to identify the action of the plant-extract admixture in the hydration process of the gypsum plaster, mixtures were analyzed at different curing times (after 0.5, 1.3, and 24 hours), and the same dosages used in studies on consistency and setting times were used here (Tables 2 and 3).

The degree of conversion was evaluated by determining the amount of chemically combined water both for the hemihydrate and for the dihydrate. The first column in table 4 defines the plaster sample, the second column is the loss of combined water in the gypsum plaster, the third one is the percentage of dihydrate in the hydrated plaster (D), the fourth one is the percentage of hemihydrate $(H)$, and the fifth column shows the degree of conversion (a).

It was observed that after 0.5 and 1 hours, the degree of conversion of the samples with 3\% and 5\% of admixture is lower than that of the control sample. The value is quite similar after 3 and 24 hours, which means that the retardant power of the admixture in the gypsum manifested considerably during the first hours of the hydration process. We also observed that dihydrate formation continued to increase over time.

Table 5 lists the data obtained from the percentage of dihydrate formed during the gypsum hydration process after $0.5,1,3$, and 24 hours. The plaster samples had the same consistency as the control sample; therefore, there was a variation in the $w / g$ ratio. The behavior of the conversion degree was similar to that of the plaster prepared with the same w/g ratio. However, the conversion values were lower, indicating lower hydration of plaster. Most likely, this is due to the higher concentration of active substances in the plant extract. Although the plaster prepared with the same $w / g$ ratio had a higher delay in its setting times compared to those prepared with the same consistency, this does not indicate that the final percentage of conversion from hemihydrate into dihydrate was lower. In general, we can say that the admixture acts as a retardant agent in the formation of the dihydrate gypsum crystals during the first hour. 
Tabla 4 / Table 4

Grado de conversión de hidratación de la pasta de yeso a igual relación a/y $(0,48)$.

Conversion degree of hydration of gypsum to the same $w / g$ ratio $(0.48)$.

\begin{tabular}{|c|c|c|c|c|c|}
\hline Horas / Hours & Muestra / Sample & Pérdida / Loss & D & H & $\alpha$ \\
\hline \multirow{3}{*}{0.5} & $1 \mathrm{a}$ & $15.40 \%$ & $68.60 \%$ & $16.78 \%$ & 0.775 \\
\hline & $3 b$ & $12.64 \%$ & $50.06 \%$ & $34.85 \%$ & 0.548 \\
\hline & $4 b$ & $9.66 \%$ & $30.03 \%$ & $54.35 \%$ & 0.38 \\
\hline \multirow{3}{*}{1} & $1 \mathrm{a}$ & $16.32 \%$ & $74.78 \%$ & $10.76 \%$ & 0.854 \\
\hline & $3 b$ & $14.05 \%$ & $59.53 \%$ & $25.62 \%$ & 0.662 \\
\hline & $4 b$ & $10.11 \%$ & $33.06 \%$ & $51.41 \%$ & 0.352 \\
\hline \multirow{3}{*}{3} & $1 \mathrm{a}$ & $17.04 \%$ & $79.62 \%$ & $6.04 \%$ & 0.917 \\
\hline & $3 b$ & $16.74 \%$ & $77.61 \%$ & $8.01 \%$ & 0.891 \\
\hline & $4 b$ & $16.76 \%$ & $77.74 \%$ & $7.88 \%$ & 0.893 \\
\hline \multirow{3}{*}{24} & $1 \mathrm{a}$ & $17.72 \%$ & $84.19 \%$ & $1.59 \%$ & 0.978 \\
\hline & $3 b$ & $17.57 \%$ & $83.18 \%$ & $2.57 \%$ & 0.965 \\
\hline & $4 b$ & $17.57 \%$ & $83.18 \%$ & $2.57 \%$ & 0.965 \\
\hline
\end{tabular}

Tabla 5 / Table 5

Grado de conversión de hidratación de la pasta de yeso a igual consistencia que la pasta control.

Conversion degree of hydration of gypsum with the same consistency of control sample.

\begin{tabular}{|c|c|c|c|c|c|}
\hline Horas / Hours & Muestra / Sample & Pérdida / Loss & D & $\mathrm{H}$ & $\alpha$ \\
\hline \multirow{3}{*}{0.5} & $1 a$ & $15.40 \%$ & $68.60 \%$ & $16.78 \%$ & 0.775 \\
\hline & $3 a$ & $12.32 \%$ & $47.91 \%$ & $36.94 \%$ & 0.522 \\
\hline & $4 a$ & $7.9 \%$ & $18.21 \%$ & $65.88 \%$ & 0.189 \\
\hline \multirow{3}{*}{1} & $1 a$ & $16.32 \%$ & $74.78 \%$ & $10.76 \%$ & 0.854 \\
\hline & $3 a$ & $13.08 \%$ & $53.01 \%$ & $31.97 \%$ & 0.583 \\
\hline & $4 a$ & $9.59 \%$ & $29.56 \%$ & $54.81 \%$ & 0.313 \\
\hline \multirow{3}{*}{3} & $1 a$ & $17.04 \%$ & $79.62 \%$ & $6.04 \%$ & 0.917 \\
\hline & $3 a$ & $16.57 \%$ & $76.46 \%$ & $9.12 \%$ & 0.876 \\
\hline & $4 a$ & $16.39 \%$ & $75.25 \%$ & $10.30 \%$ & 0.860 \\
\hline \multirow{3}{*}{24} & $1 a$ & $17.72 \%$ & $84.19 \%$ & $1.59 \%$ & 0.978 \\
\hline & $3 a$ & $17.49 \%$ & $82.64 \%$ & $3.10 \%$ & 0.957 \\
\hline & $4 a$ & $17.36 \%$ & $81.77 \%$ & $3.95 \%$ & 0.946 \\
\hline
\end{tabular}

\subsection{Influencia del aditivo en las resistencias mecánicas a flexo-tracción y compresión}

Para este ensayo se elaboraron probetas prismáticas a igual consistencia y a igual relación a/y de tal manera que se pudiera apreciar la variación en las resistencias mecánicas debida a la incorporación del aditivo. Las dosificaciones utilizadas son las mismas que se presentan en las Tablas 2 y 3.

En la Figura 2, se exponen los datos de las resistencias a flexo-tracción y compresión en probetas de pastas de yeso a igual consistencia. En el Gráfico 2a se observan las resistencias a flexo-tracción de las probetas preparadas con igual consistencia que la muestra control (muestras 1a, 2a, 3a y 4a en la Tabla 2). Observamos que hay un leve incremento de la resistencia cuando adicionamos $1 \%$ y $3 \%$ de aditivo. Con un $5 \%$ la resistencia se iguala a la resistencia de la probeta control. Este incremento

\subsection{Influence of the admixture on flexural and compressive strengths}

For this test, we prepared prismatic test samples with the same consistency and $w / g$ ratio so that we could observe the variation in the mechanical strengths resulting from incorporating admixture. The dosages used are equal to those described in tables 2 and 3.

Figure 2 shows the data on the flexural and compressive strengths of gypsum plaster test samples that have the same consistency. Graph 2a shows the flexural strengths of the test samples prepared with the same consistency as the control sample (samples $1 a, 2 a, 3 a$, and $4 a$ in Table 2). Upon adding $1 \%$ and $3 \%$ of admixture, we observed that there was a slight increase in strength. With 5\%, the strength equals the strength of the control test samples. This increase in 
de la resistencia está relacionado directamente con la densidad de las probetas con aditivo.

El Gráfico 2b muestra las resistencias a compresión de las probetas preparadas con igual consistencia que la muestra control. Se observa el mismo comportamiento de la resistencia a flexo-tracción. La reducción en la dosificación de agua cuando se incrementa la cantidad de aditivo no viene acompañada de un aumento importante de la densidad, lo que significa que existe una cierta oclusión de aire activada por el aditivo orgánico. strength is directly related to the density of the test samples with admixture.

Graph $2 b$ shows the compressive strengths of the test samples prepared with the same consistency as the control sample. The behavior observed in the flexural strength tests was also seen here. Reducing the water dosage while increasing the amount of admixture does not lead to a significant increase in density. This means that some sort of air entrainment is activated by the organic admixture.

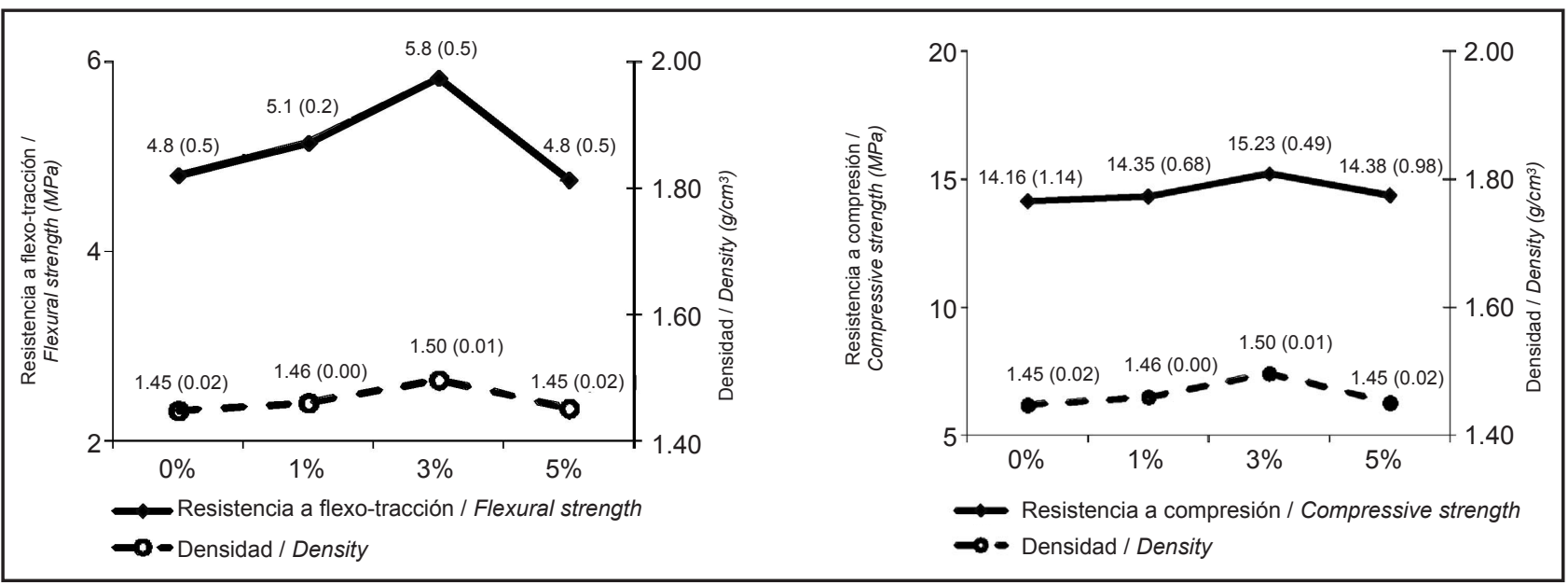

Figura 2. Resistencias mecánicas: a) resistencia a flexo-tracción o densidad a igual consistencia vs. porcentaje de aditivo; b) resistencia a compresión o densidad a igual consistencia vs. porcentaje de aditivo

Figure 2. Mechanical strengths: a) flexural strength or density with same consistency vs. percent of admixture, b) compressive strength or density whit same consistency vs. admixture percent.

En la Figura 3, se ilustran los datos de las resistencias a flexo-tracción y compresión de probetas con pastas de yeso a igual relación a/y. En el Gráfico 3a se muestran los datos correspondiente a las resistencias a flexo-tracción y la densidad de las probetas de yeso preparadas con igual relación a/y que la muestra control. Corresponden a las muestras $1 a, 2 b, 3 b$ y $4 b$ de laTabla 3 . El incremento del extracto produce una disminución de la resistencia a flexotracción, aunque con $3 \%$ y $5 \%$ la diferencia es muy pequeña. Este comportamiento se asocia al descenso de la densidad, aproximadamente $17 \%$, o sea al aumento de la porosidad de la probeta, lo que sugiere que el aditivo produce un incremento del aire ocluido en la pasta. Esta disminución en la densidad se podría calificar de moderada comparado con otros aditivos como el sulfato de aluminio, el lauril sulfato de sodio, el bicarbonato de amonio o el de sodio que reducen la densidad del yeso entre el $30 \%$ y el $35 \%$ (9).

En el Gráfico 3b se muestran los datos correspondientes a las resistencias a compresión de las probetas de yeso preparadas con igual relación a/y que la muestra control. La tendencia es similar a la de la resistencia a
Figure 3, shows the data of the flexural and compressive strengths of test samples with gypsum plaster at the same $w / g$ ratio. Graph $3 a$ shows the data for the flexural strengths and density of the gypsum test samples that were prepared with the same $w / g$ ratio as the control sample. They correspond to samples $1 a, 2 b, 3 b$, and $4 b$ from Table 3. Increasing the extract decreased the flexural strength; however, an increase of $3 \%$ or $5 \%$ caused a very small decrease. This behavior is associated with the decrease in density (approximately 17\%); in other words, it is associated with the test specimen's increase in porosity, thus suggesting that the admixture increases the air entrained in the plaster. This decrease in density could be considered moderate compared to other admixtures such as aluminum sulfate, sodium lauryl sulfate, ammonium bicarbonate, or sodium bicarbonate, which reduce gypsum density between $30 \%$ and $35 \%$ (9).

Graph $3 b$ shows the data regarding the compressive strengths of the gypsum test samples that were prepared with the same $\mathrm{w} / \mathrm{g}$ ratio as the control sample. The trend is similar to that of the flexural strength: 
flexo-tracción: cuando adicionamos aditivo la resistencia a compresión disminuye. Sin embargo, es destacable el hecho de que la adición de $1 \%$ de aditivo da lugar a un descenso significativo en la densidad pero la resistencia a compresión se mantiene con respecto al control. Ello significa que la presencia de pequeñas cantidades de aditivo produce un material con una distribución y tamaño de poros adecuado. Cuando se incrementa la cantidad del extracto la disminución en la resistencia mecánica se podría atribuir a una mayor cantidad de macroporos. compressive strength decreased as we added admixture. However, it is worth noting that adding $1 \%$ of admixture resulted in a significant decrease in density, yet the compressive strength remains unchanged with respect to the control sample. This means that the presence of small amounts of admixture produces a material with the appropriate distribution and pore size. The fact that mechanical strength decreased if the amount of extract added increased could be due to a higher amount of macropores.

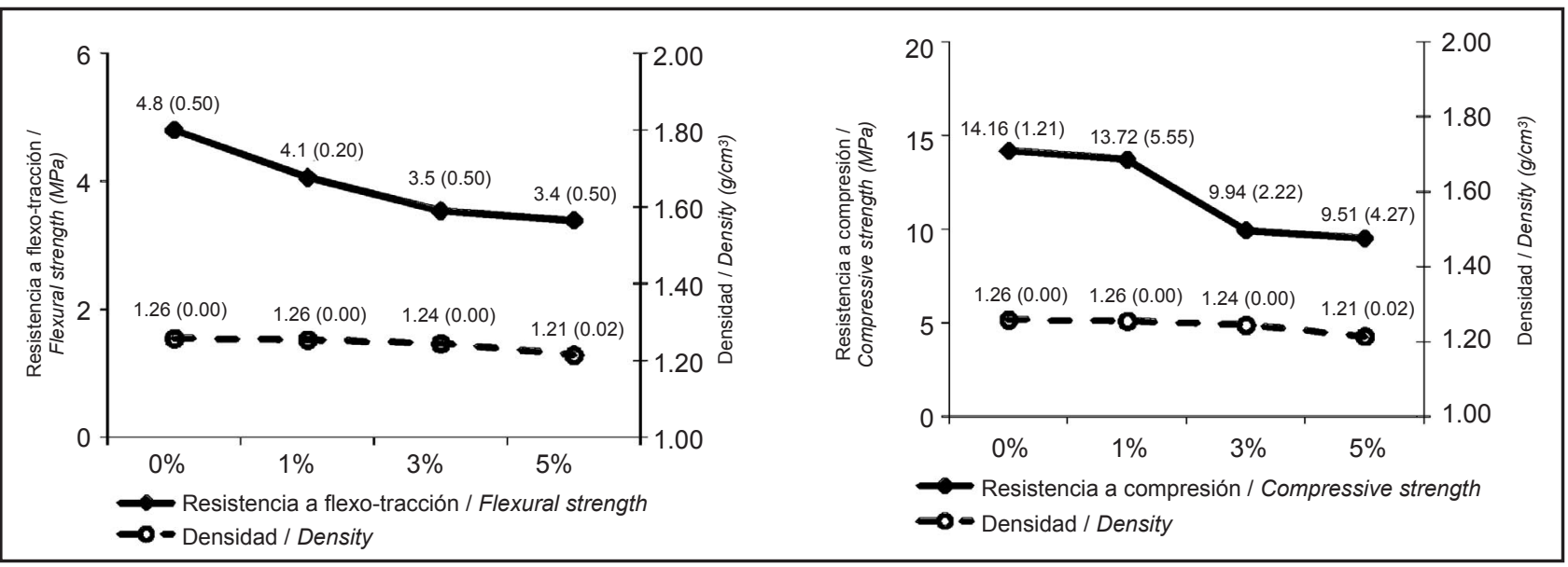

Figura 3. Resistencia mecánica a flexo-tracción y compresión en pastas de yeso a igual relación a/y: a) resistencia a flexo-tracción a igual relación $a / y ; b)$ resistencia a compresión a igual relación $a / y$.

Figure 3. Mechanical resistance to flexural and compressive strengths in plaster pastes with the same a/y ratio: a) resistance to flexural strength to the same a/y ratio and b) compressive strength to the same a/y ratio.

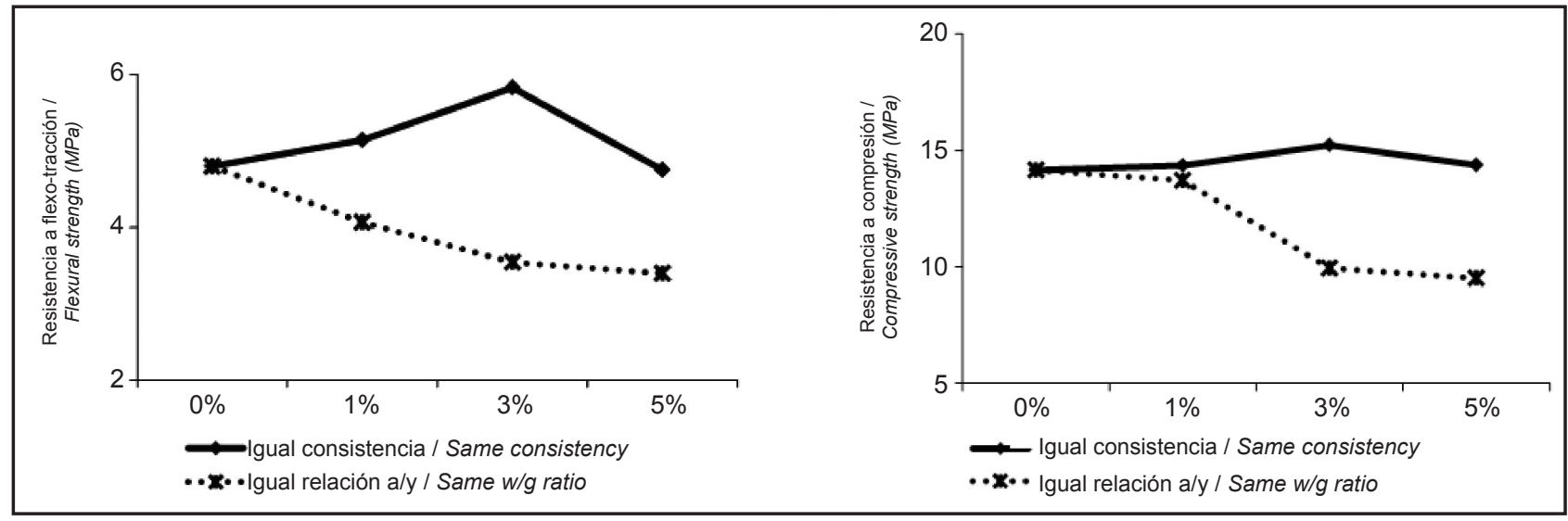

Figura 4. Resistencias mecánicas: a) comparación entre resistencia a flexo-tracción a igual consistencia e igual relación a/y; b) comparación entre resistencia a compresión a igual consistencia e igual relación a/y.

Figure 4. Mechanical strengths: a) comparison between flexural strength with the same consistency and the same a/y ratio b) comparison between compressive strength with the same consistency and the same a/y ratio.

Comparativamente, observamos que la diferencia entre la resistencia a compresión en una pasta de yeso a igual consistencia y la otra a igual relación $\mathrm{a} / \mathrm{y}$, con porcentajes de aditivo de $1 \%$, es muy pequeña, pero logramos buenos aumentos con buena consistencia de la pasta. La diferencia se hace notoria cuando utilizamos 3 y $5 \%$ de aditivo. Ver Figuras 4a y 4b.
Comparatively, we observed that the difference between the compressive strength of a gypsum plaster sample with the same consistency, and that of another plaster sample with the same $w / g$ ratio -both with $1 \%$ of admixture- is very small. However, we achieved good increases with good plaster consistency. The difference is remarkable when $3 \%$ and $5 \%$ of admixture is used. See Figures $4 a$ and $4 b$. 


\section{CONCLUSIONES}

Del estudio realizado se deducen las siguientes conclusiones:

1. Con $1 \%$ de aditivo se logra disminuir el agua de amasado aproximadamente $11 \%$ respecto a la muestra control, y se logra conservar la misma consistencia. Con 3 y $5 \%$ el agua se disminuye en $16 \%$ y $17 \%$, aproximadamente. Esto indica que a partir de 3\%, el efecto del aditivo empieza a no ser significativo. Como consecuencia de la disminución del agua de amasado, se incrementan las resistencias mecánicas con $1 \%$ y $3 \%$ de aditivo. Con $5 \%$ se conserva prácticamente igual a la muestra control.

2. Si conservamos la misma relación a/y de la muestra control encontramos que con $1 \%$ de aditivo se incrementa la consistencia de la pasta aproximadamente en un $14 \%$, y con el $3 \%$ de aditivo en $36 \%$. La consecuencia de este incremento de plasticidad se observa en la disminución de las resistencias mecánicas porque el efecto espumante del aditivo se incrementa con la mayor cantidad de agua y se aumenta la porosidad de la pasta.

3. El tiempo inicial y final de fraguado se incrementa a medida que se aumenta la cantidad de aditivo. Con $5 \%$ de aditivo se logra aumentar en más de 1,5 horas el tiempo final de fraguado lo que coincide con estudios de otros aditivos retardantes como látex o el ácido cítrico. El índice de conversión de la hidratación de la pasta corrobora que a 1 hora de fraguado, con $3 \%$ y $5 \%$ de aditivo, el porcentaje de dihidrato producido es menor que el de la muestra control.

4. La adición del extracto de la planta mejora considerablemente la plasticidad de la pasta, al tiempo que retrasa los tiempos iniciales y finales de fraguado. La mejora de estas propiedades ayudaría en la aplicación de yesos de construcción, y a su aspecto final.

\section{AGRADECIMIENTOS}

J. C. Ochoa agradece a la Fundación Carolina por la beca asignada para la realización de esta investigación; a la Universidad Nacional de Colombia por el tiempo cedido y al Instituto de Ciencias y Tecnología del Hormigón ICITECH de la Universitat Politécnica de Valencia por los recursos humanos y materiales.

\section{CONCLUSIONS}

The following are the conclusions drawn from this study:

1. Adding $1 \%$ of admixture makes it possible to reduce mixing water in approximately $11 \%$, in contrast with the control sample, whilst keeping the same consistency. Adding 3\% and 5\% of admixture reduces mixing water in approximately $16 \%$ and $17 \%$. This means that the effect of the admixture starts to become non-significant after 3\%. As a result of decreasing the amount of mixing water, mechanical strengths increase with $1 \%$ and $3 \%$ of admixture. With $5 \%$ of it, they are practically the same as the ones observed in the control sample.

2. When we kept the $\mathrm{w} / \mathrm{g}$ ratio of the control sample unchanged, we observed that, with $1 \%$ of admixture, the consistency of the plaster increased approximately in 14\%; if the admixture was 3\%, this figure increased to $36 \%$. This increase in plasticity results in the reduction of mechanical strengths since the foaming effect of the admixture increases as there is more water, thus increasing plaster porosity.

3. Initial and final setting times increased as more admixture was added. With 5\% of admixture, the final setting time can be increased in more than 1.5 hours. This is consistent with other studies on retardant admixtures such as latex or citric acid. The conversion index for plaster hydration confirms that after 1 hour of setting with $3 \%$ and $5 \%$ of admixture, the percentage of dihydrate produced was less than that of the control sample.

4. Adding the plant extract considerably improves the plasticity of the plaster, whilst increasing the initial and final setting times. The improvement of these properties would help in the application of construction plaster and its final appearance.

\section{ACKNOWLEDGEMENTS}

J.C. Ochoa would like to thank Fundación Carolina (the Carolina Foundation) for the scholarship granted to conduct this study, Universidad Nacional de Colombia(National University of Colombia) for the time granted, and the Instituto de Ciencia y Tecnología del Hormigón-ICITECH (Institute of Science and Technology of Concrete) at Universitat Politécnica de Valencia for the human and material resources. 


\section{BIBLIOGRAFÍA / BIBLIOGRAPHY}

(1) Hornbostel, C.: "Tipos, usos y aplicaciones", Materiales para la Construcción, Limusa S.A y C.V, 2002.

(2) Camarini, G.; de Milito, J. A.: "Gypsum hemihydrate-cement blends to improve renderings durability", Constr. Build. Mater., in press (2011). doi:10.1016/j.conbuildmat.2011.04.048.

(3) Arikan, M.: "The optimization of a gypsum-based composite material". Cem. Concr. Res., vol. 32, n 11 (2002), pp. 1725-1728. doi:10.1016/S0008-8846(02)00858-X.

(4) Colak, A.: "Physical and mechanical properties of polymer-plaster composites", Materials Letters, vol. 60, n 16 (2006), pp. 19771982.doi:10.1016/j.matlet.2005.12.062.

(5) Rubio Avalos, J.; Manzano Ramírez, A.; Luna Barcenas, J., Pérez Robles, J.; Alonso Guzmán, E.; Contreras García, M.; González Hernández, J.: "Flexural behaviour and microstructure analysis of a gypsum-SBR composite material", Materials Letters, vol. 59, $\mathrm{n}^{\circ} 2-3$ (2005), pp. 230-3.doi:10.1016/j.matlet.2004.07.054.

(6) Çolak, A.: "Characteristics of acrylic latex-modified and partially epoxy-impregnated gypsum", Cem. Concr. Res., vol. $31, \mathrm{n}^{\circ} 11$ (2001), pp. 1539-1547. doi:10.1016/S0008-8846(01)00575-0.

(7) Chindaprasirt, P.; Boonserm, K.; Chairuangsri, T.; Vichit-Vadakan, W.; Eaimsin, T.; Sato, T; Pimraksa, K.: "Plaster materials from waste calcium sulfate containing chemicals, organic fibers and inorganic additives", Constr. Build. Mater., in press (2011). doi:10.1016/j. conbuildmat.2011.03.004.

(8) García Santos, A.: "PPF-reinforced, ESP-lightened gypsum plaster", Mater. Construcc., vol. 59, n 293 (2009), pp. $105-124$. doi:10.389/mc.2009.41107.

(9) Rubio Avalos, J.; Manzano Ramírez, A.; Yánez Limón, J.; Contreras García, M.; Alonso Guzmán, E.; González Hernández, J.: "Development and characterization of an inorganic foam obtained by using sodium bicarbonate as a gas generator", Constr. Build. Mater., vol. 19, n 7, (2005), pp. 543-549. doi:10.1016/j.conbuildmat.2004.12.001.

(10) Çolak, A.: "Density and strength characteristics of foamed gypsum", Cem. Concr. Comp., vol. 22, n 3 (2000), pp. 193-200. doi:10.1016/S0958-9465(00)00008-1.

(11) Vimmrová, A.; Keppert, M.; Svoboda, L.; Černý R.: "Lightweight gypsum composites: Design strategies for multi-functionality", Cem. Concr. Comp., vol. 33, n 1 (2011). doi:10.1016/j.cemconcomp.2010.09.011.

(12) Izaguirre, A.; Lanas, J.; Álvarez, J. I.: "Effect of a biodegradable natural polymer on the properties of hardened lime-based mortars", Mater. Construcc., vol. 1, no 302 (2011), pp. 257-274.

(13) Chandra, S.; Eklund, L.; Villareal, R.: "Use of cactus in mortars and concrete", Cem. Concr. Res., vol. 28, nO 1 (1998), pp. $41-51$.

(14) UNE EN-13279-1: Yesos de construcción y conglomerantes a base de yeso para la construcción. Parte 1: Definiciones y especificaciones (2006).

(15) UNE EN-13279-2: Yesos de construcción y conglomerantes a base de yeso para la construcción. Parte 2: Métodos de ensayo (2006).

(16) Borrachero, M. V.; Payá, J.; Bonilla, M.; Monzó, J.: "Nuevos procedimientos de análisis termogravimétricos para la caracterización de materiales de construcción: aplicación a yesos". VIII Congreso Nacional de Materiales, (2004), pp. 89-96. 